\title{
Steroid avoidance in liver transplantation
}

\author{
José Oberholzer MD, Mohammed Al-Saghier MD, Norman M Kneteman MD
}

J Oberholzer, M Al-Saghier, NM Kneteman. Steroid avoidance in liver transplantation. Can J Gastroenterol 2004;18(Suppl C):5C-11C.

Corticosteroids have always played a valuable role in transplantation. Unfortunately, they are subject to a wide range of side effects, such as hyperlipidemia, hypertension, diabetes mellitus, osteoporosis, growth retardation and Cushingoid appearance. Steroids may also exacerbate problems that existed before surgery, including malignancy, hepatitis B and hepatitis C. New, powerful immunosuppressants have allowed steroid use to be reduced or avoided altogether, but use of these regimens is not simple and may be associated with late acute rejection and recurrence of autoimmune disease. The present review examines the rationale for steroid avoidance in liver transplantation and assesses the new regimens that are currently being developed.

Key Words: Immunosuppression; Liver transplantation; Mycophenolate mofetil; Steroids

\section{Éviter les stéroïdes en cas de greffe du foie}

Les corticoïdes ont toujours joué un rôle précieux en cas de greffe. Malheureusement, ils provoquent une vaste gamme d'effets secondaires, tels que l'hyperlipidémie, l'hypertension, le diabète, l'ostéoporose, le retard de croissance et les traits cushingoïdes. Les stéroïdes peuvent également exacerber des problèmes présents avant l'opération, y compris une malignité, une hépatite B et une hépatite C. De nouveaux immunosuppresseurs puissants permettent de réduire ou même d'éviter les stéroïdes, mais ces schémas posologiques ne sont pas simples et peuvent s'associer à un rejet tardif aigu et à une récurrence de la maladie auto-immune. La présente analyse traite de la justification d'éviter les stéroïdes en cas de greffe du foie et évalue les nouveaux schémas posologiques en cours d'élaboration.

\footnotetext{
Corticosteroids have long been used for the induction and maintenance of immunosuppression and as an antirejection treatment. Unfortunately, steroids also cause numerous adverse effects $(1,2)$. At high dosages, corticosteroids induce apoptosis of peripheral $\mathrm{T}$ lymphocytes, a key factor in the effective reversal of acute rejection (3). The exact mechanism by which steroids prevent rejection has been elusive, with recent studies supporting inhibition of cytokine messenger (m) RNA transcription (4-6), especially for interleukin (IL)-2. Steroids not only inhibit cytokine production, but also interfere with IL-2 signal transduction (7). They have a variety of additional immunological effects, such as inhibition of chemokine synthesis and repression of genes that encode cell surface receptors and adhesion molecules that are involved in lymphocyte activation, migration and recruitment $(6,8)$.

Typical steroid-related side effects encountered in transplant patients are weight gain and obesity with Cushingoid features, hyperlipidemia, diabetes mellitus, hypertension, cataracts (9) and bone diseases such as avascular necrosis and osteoporosis (10). Osteoporosis may occur in as many as 50\% of patients after six months of treatment with steroids, and can lead to fractures after minimal trauma, as well as reduced quality of life (11).
}

A variety of nonsteroidal immunosuppressive agents have become available, thereby increasing interest in effective strategies that reduce the use and considerable morbid impact of corticosteroids.

\section{STEROIDS IN PEDIATRIC TRANSPLANT RECIPIENTS}

Most steroid-induced side effects seen in adults are also encountered in children. In addition, growth retardation and Cushingoid features are of particular concern in the pediatric transplant population.

\section{Growth retardation}

Growth after transplantation is determined by a variety of factors, including the underlying disease, pretransplant nutritional status, post-transplant complications and the nature of the immunosuppressive regimen. Steroids inhibit the growth of children undergoing solid organ transplantation (12). Although the underlying mechanisms have not been completely elucidated, an inverse correlation between the degree of suppression of endogenous cortisol production and growth velocity has been described (13). 
Steroid withdrawal in pediatric liver transplant recipients was described as early as 1989 by Margarit et al (14). In this pilot trial, patients were given cyclosporine (CsA)- and prednisonebased immunosuppression. Prednisone dosage was reduced every second week by $0.1 \mathrm{mg} / \mathrm{kg} /$ day, reaching $0.2 \mathrm{mg} / \mathrm{kg} /$ day at month 6 after transplantation; thereafter, steroids were withdrawn within two months. Five of the 15 patients presented with a cellular rejection episode and two patients developed chronic rejection requiring retransplantation.

Dunn et al (15) attempted steroid withdrawal in 28 of 37 children beyond 18 months after liver transplantation on CsA-based immunosuppression. Increased growth velocity was observed after steroid withdrawal. Three of the 28 children experienced cellular rejection, requiring the reintroduction of steroids. Subsequent studies using tacrolimus showed that steroids could be withdrawn safely in most pediatric liver transplant recipients with an acceptable risk of reversible rejection of approximately $30 \%$ (16), and a beneficial effect on growth (17). Growth velocity after liver transplantation seems to be inversely related to the cumulative yearly steroid dosage (expressed as $\mathrm{mg} / \mathrm{kg}$ ); after steroid withdrawal, it returns nearly to normal (18).

\section{Cushingoid side effects}

Physiognomic disfigurement induced by corticosteroids is a significant problem in pediatric organ transplant recipients, especially female adolescents, and may result in nonadherence with treatment. Work involving kidney transplant recipients suggests that the development and persistence of Cushingoid features may be related to decreased total body clearance of prednisolone $(19,20)$, which in turn may be due to impaired renal or hepatic function. Minimizing steroid dosage may improve both quality of life and adherence in children and adults.

\section{DIABETES MELLITUS}

Post-transplant diabetes mellitus (PTDM) occurs in up to $20 \%$ of patients undergoing organ transplantation (21). On the other hand, diabetes mellitus may be a complication of end-stage liver disease, which can improve after liver transplantation. A study from Berlin found that 66 of 618 patients were diabetic before transplantation and that, in $37(56 \%)$ of these cases, it seemed to resolve after the procedure (22).

New-onset glucose intolerance and diabetes mellitus are major problems after liver transplantation. Several risk factors have been identified, including obesity, genetic predisposition to type II diabetes (23), hepatitis C virus (HCV) infection (24) and calcineurin inhibitors (CNIs) (25). New-onset PTDM was observed in 39 of 552 patients (7.2\%) in the Berlin series (22).

In a recent retrospective analysis, Baid et al (26) showed that the prevalence of PTDM was significantly associated with HCV positivity (64\% versus 28\%, $\mathrm{P}=0.0001)$. Among $\mathrm{HCV}$-positive patients, cumulative mortality was significantly higher in patients with PTDM (56\% versus 14\%, P=0.001). HCV infection and methylprednisolone boluses were found to be independent risk factors for the development of diabetes mellitus after transplantation (26).

It is widely accepted that steroid withdrawal is beneficial for glucose homeostasis (27-29), although the Berlin study (22) failed to show a difference in the prevalence of diabetes mellitus between conventional and steroid-free regimens (10.4\% versus $12.5 \%$, respectively). Animal studies in islet transplantation have shown that steroids dramatically exacerbate the diabetogenic potential of CNIs (30).
PTDM worsens the long-term prognosis of transplant recipients (31). Insulin-dependent diabetes mellitus is a major risk factor for cardiovascular disease, which is the leading cause of long-term morbidity and mortality in liver transplant recipients (22).

\section{STEROIDS AND RECURRENCE OF VIRAL HEPATITIS}

\section{Hepatitis B}

In vitro data indicate that steroids, but not azathioprine, tacrolimus or CsA, increase the expression of viral antigen in cultured hepatocytes isolated from hepatitis B virus (HBV)infected patients $(32,33)$. Petersen et al (34) showed that steroids increase the replication rate of woodchuck hepatitis virus in a mouse model of hepatocyte xenotransplantation. In clinical practice, the impact of steroids on HBV recurrence after liver transplantation is not clear, but several observations outside the context of transplantation support the view that they have an adverse effect on the course of HBV infection. Pilot studies indicate that steroids increase the rate of HBV replication in patients with chronic, but not acute, hepatitis $(35,36)$. Severe forms of hepatitis have been observed in HBV carriers who were given steroids for the treatment of hematological malignancy $(37,38)$.

Modern antiviral strategies, including lamivudine and hepatitis B immune globulin, have greatly reduced the rate of HBV recurrence after liver transplantation (39-43).

\section{$\mathrm{HCV}$}

To date, there is no completely effective treatment for HCV, and recurrence after transplantation is universal (44). HCV reinfection after liver transplantation significantly impairs patient and graft survival $(45-47)$, particularly if it occurs early $(48,49)$.

The pathogenesis of HCV recurrence after liver transplantation is poorly understood. The severity of its impact on the liver graft probably depends on both the pathogenicity of the virus and the immune responsiveness of the recipient. Although the former may be related to the viral genotype $(45,50)$, the viral load is also likely to influence the course of $\mathrm{HCV}$ recurrence $(51,52)$. A retrospective analysis of the consequences of using OKT3 (Janssen-Ortho, Canada) (for steroidresistant liver graft rejection) showed that increased immunosuppression contributes to poor outcome in HCVinfected recipients (53). Both experimental and clinical data indicate that immunosuppression, especially with steroids, increases the severity of HCV recurrence by affecting the viral load and the immune responsiveness of the recipient $(54,55)$. A four- to 100 -fold increase in serum HCV RNA levels has been documented after the administration of methylprednisolone to treat acute rejection (56), and other investigators have also shown that steroids boost HCV replication (56-59). However, no correlation was found between quantities of genomic HCV RNA in serum and relative intrahepatic viral replication, either before or after liver transplantation (52). Therefore, it is possible that the increased HCV RNA levels observed after steroid treatment are due to decreased immunemediated viral clearance, rather than to increased viral replication.

Thus far, there are no conclusive clinical data comparing steroid-free immunosuppressive protocols with classical regimens that include steroids (60). A retrospective analysis by Brillanti et al (55) suggests that long-term steroid therapy, 
slowly tapered over time, may actually prevent the most aggressive forms of recurrent $\mathrm{HCV}$ disease in liver transplant recipients. Only preliminary data are currently available from ongoing comparative studies investigating the effects of early steroid withdrawal or complete steroid avoidance on $\mathrm{HCV}$ recurrence $(60,61)$.

\section{STEROIDS AND RECURRENCE OF LIVER MALIGNANCIES}

Liver transplantation is an excellent therapeutic option for selected patients with hepatocellular carcinoma (62-64), although immunosuppression likely accelerates recurrence. In a recent retrospective multivariate analysis (64), the amount of CsA given in the first 12 months post-transplantation and the tumour stage (according to the International Union Against Cancer Tumour, Node, Metastases [TNM] classification system) were independent prognostic factors for tumour recurrence. A high dosage of CsA administered during postoperative months three to 12 was associated with a significantly lower recurrence-free survival. A cut-off in the cumulative CsA dosage was determined by applying a receiver-operating characteristic curve. Recurrence-free survival at five years was $76 \%$ for patients receiving more than $116,834 \mathrm{mg}$ of CsA in the first 12 postoperative months, compared with $93 \%$ for those receiving lower dosages. The same retrospective analysis found that the cumulative dosage of steroids and azathioprine administered during the first postoperative year was not correlated with tumour recurrence. Moreover, immunosuppressive regimens that included CsA, azathioprine and steroids had similar effects to those that included only CsA and steroids, and that CsA was equivalent to tacrolimus (64).

It has been found that recurrent hepatocellular carcinomas grew significantly more quickly in transplant recipients under immunosuppression than in patients with the same disease who underwent liver resection without transplantation (65). CsA also accelerates tumour progression in animal models of hepatocellular carcinoma (66).

On the other hand, the effect of steroids per se on tumour recurrence has not been extensively investigated. Early clinical trials suggested that discontinuation of corticosteroids soon after transplantation may reduce recurrence rates (62). In a retrospective analysis by the Milan group (67), steroid treatment beyond six months after transplantation increased the risk of tumour recurrence fourfold. Patients weaned from steroids at six months post-transplantation and maintained on CsA monotherapy (43 cases) or on CsA plus azathioprine (four cases) had four-year tumour-free survival rates of $86 \%$ and $75 \%$, respectively, whereas patients on CsA and steroids (22 cases) or azathioprine (nine cases) had four-year tumourfree survival rates of $44 \%$ and $37 \%$, respectively. Controlled trials on the impact of steroid withdrawal on tumour recurrence have not yet been reported.

These clinical and experimental data indicating a relationship between CNIs and tumour recurrence suggest that the recommendation of steroid avoidance in favour of increasing the CNI dosage should be approached with caution. Steroid withdrawal should serve to decrease the total immunosuppressive load, which may be one of the most important determinants of tumour recurrence. If steroid tapering or avoidance are unlikely to increase the risk of organ rejection, then regimens that reduce or avoid the use of steroids and CNIs would be appropriate for patients undergoing transplantation for liver

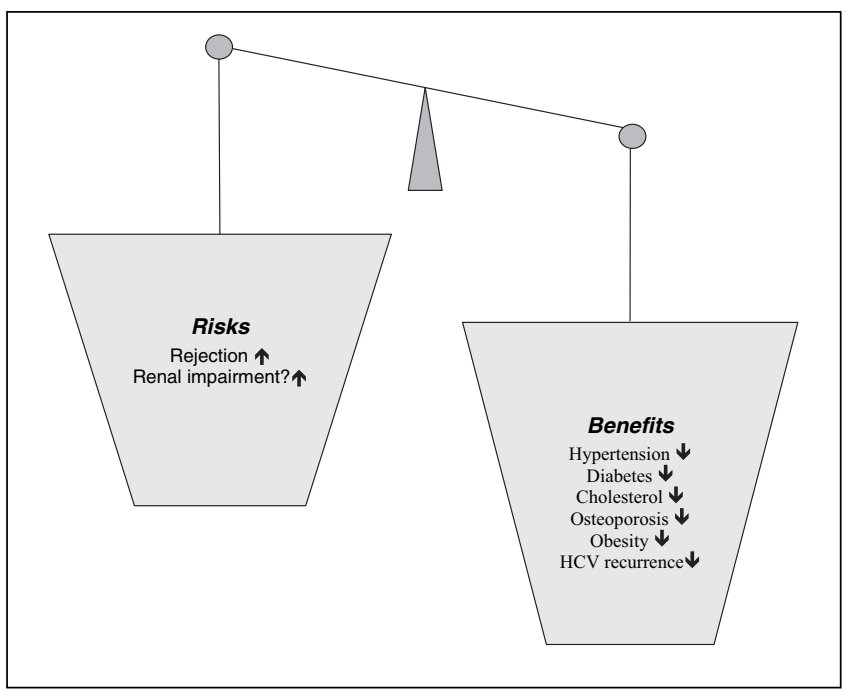

Figure 1) Risk-to-benefit ratio for steroid withdrawal or avoidance. HCV Hepatitis C virus; $\uparrow$ Increased; $\downarrow$ Decreased

malignancies. Newer agents with antitumour activity, such as sirolimus $(68,69)$, may have theoretical advantages but need further exploration.

Steroid avoidance has only recently been introduced in liver transplantation. Long term follow-up studies, ideally prospective trials, are needed to evaluate its impact on tumour recurrence.

\section{APPROACHES TO STEROID AVOIDANCE}

Although most candidates for liver transplantation are prone to steroid-induced side effects (Figure 1), some are at particularly high risk. Patients with cholestatic liver disease frequently have osteoporosis even before transplantation, and this would be adversely affected by steroid therapy. HCV and obesity are both associated with an increased risk of PTDM. Given the overall risk of PTDM of $10 \%$ to $15 \%$ and the fact that it may not be reversible with steroid withdrawal, one could argue for the routine avoidance of steroids, unless a contrary argument exists.

Despite the availability of more potent immunosuppressants, steroids continue to be used in the short or long term in most liver transplantation protocols. The use of such agents as tacrolimus and mycophenolate mofetil (MMF) allows most patients to taper off steroids, or avoid them altogether, without increasing the risk of immunological graft loss.

Steroid withdrawal or avoidance may not always be possible. For example, steroid reintroduction may be necessary for late rejection episodes, recurrent autoimmune disease or renal impairment due to CNIs. Other medical conditions, such as inflammatory bowel disease in patients with primary sclerosing cholangitis, may require chronic steroid treatment. In the majority of cases, however, steroid withdrawal can be attempted safely, and its reintroduction always remains an option (70).

Several trials have shown that steroid therapy can be successfully withdrawn shortly after liver transplantation, thereby decreasing cardiovascular risk factors and improving bone metabolism (29,71-73). Other investigators have reported less of an impact $(74,75)$ (Tables 1 and 2). Unfortunately, most studies have been small and either uncontrolled or retrospective; caution must be used when interpreting the results. 
TABLE 1

Studies on late steroid withdrawal (SW) after liver transplantation

\begin{tabular}{|c|c|c|c|c|c|}
\hline Reference (year), n & Immunosuppression & Time of SW & $\begin{array}{l}\text { Frequency } \\
\text { of rejection }\end{array}$ & Rate of SW* & Impact of SW \\
\hline $\begin{array}{l}\text { Margarit et al (14) } \\
\text { (1989), } n=18\end{array}$ & CsA & 3 to 12 months & $6 / 18(33 \%)$ & $\begin{array}{l}11 / 18 \\
(61 \%)\end{array}$ & $\begin{array}{l}\text { Better growth, reduction of Cushingoid } \\
\text { features and hirsutism in a pediatric } \\
\text { population }\end{array}$ \\
\hline $\begin{array}{l}\text { Padbury et al (27) } \\
\text { (1993), } n=197\end{array}$ & $\begin{array}{l}C s A+A Z A(n=57) \text { versus } \\
\text { CsA monotherapy }(n=97)\end{array}$ & 3 months & $12 / 154(7.8 \%)$ & $\begin{array}{c}168 / 197 \\
(85 \%)\end{array}$ & $\begin{array}{l}\text { Reduced rate of infections and diabetes } \\
\text { mellitus, as well as a reduced need for } \\
\text { antihypertensive medications; steroids } \\
\text { reintroduced in } 14 \text { of } 168 \text { patients }\end{array}$ \\
\hline $\begin{array}{l}\text { McDiarmid et al (71) } \\
\quad(1995), n=64\end{array}$ & $\begin{array}{l}C s A+A Z A+P(n=31) \\
\text { versus CsA + AZA }(n=33) \\
\quad \text { (randomized) }\end{array}$ & 1 year & $\begin{array}{l}2 / 31(6 \%) \\
2 / 33(6 \%)\end{array}$ & $\begin{array}{l}30 / 33 \\
(91 \%)\end{array}$ & $\begin{array}{l}\text { Improvement in lipid profile in a population } \\
\text { of } 42 \text { adults and } 22 \text { pediatric patients }\end{array}$ \\
\hline $\begin{array}{l}\text { Stegall et al (28) } \\
\quad(1997), n=52\end{array}$ & $\begin{array}{l}\text { CsA }(n=28) \text { versus } C s A+P \\
\quad(n=24) \text { (case-control study) }\end{array}$ & 2 years & $\begin{array}{l}4 / 28(14 \%) \text { in SW } \\
\text { group; } 1 / 24(4.2 \%)\end{array}$ & $\begin{array}{l}25 / 28 \\
(90 \%)\end{array}$ & $\begin{array}{l}\text { Decrease in the prevalence of diabetes, } \\
\text { hypertension and hypercholesterolemia }\end{array}$ \\
\hline $\begin{array}{l}\text { Belli et al (74) } \\
\qquad(1998), n=104\end{array}$ & $\begin{array}{l}C s A+P(n=50) \text { versus } \\
\quad C s A(n=54)(\text { randomized })\end{array}$ & 3 months & $\begin{array}{l}3 / 37(8 \%) \mathrm{CsA}+\mathrm{P} \\
\quad \text { and } 2 / 51(4 \%) \mathrm{CsA}\end{array}$ & $\begin{array}{l}50 / 51 \\
(98 \%)\end{array}$ & $\begin{array}{l}\text { Reduced rate of hypertension and diabetes } \\
\text { after SW; obesity, cholesterol levels and } \\
\text { recurrence of hepatitis were not } \\
\text { significantly different after SW }\end{array}$ \\
\hline $\begin{array}{l}\text { Gomez et al (29) } \\
\text { (1998), } n=86\end{array}$ & $\begin{array}{l}C s A \pm A Z A(n=14) \text { versus } \\
\qquad \operatorname{CsA}(n=72)\end{array}$ & 1 year & $0 \%$ & $100 \%$ & $\begin{array}{l}\text { Less diabetes mellitus, reduction in blood } \\
\text { pressure in hypertensive patients }\end{array}$ \\
\hline $\begin{array}{l}\text { McAlister et al (83) } \\
\text { (2001), } n=56\end{array}$ & Tac + Sir & 3 months & $8 / 56(14 \%)$ & $\begin{array}{l}51 / 56 \\
(91 \%)\end{array}$ & $\begin{array}{l}\text { Only one in } 56 \text { patients developed } \\
\text { diabetes; new-onset hypertension in } 7 \%\end{array}$ \\
\hline
\end{tabular}

${ }^{*}$ Percentage of patients ultimately withdrawn from steroid. AZA Azathioprine; CsA Cyclosporine; P Prednisone; Sir Sirolimus; Tac Tacrolimus

TABLE 2

Studies on early steroid withdrawal (SW) after liver transplantation

\begin{tabular}{|c|c|c|c|c|c|}
\hline Reference (year), n & Immunosuppression & Time of SW & $\begin{array}{l}\text { Frequency of } \\
\text { rejection of SW }\end{array}$ & Rate of SW* & Impact of SW* \\
\hline $\begin{array}{l}\text { Stegall et al (84) } \\
\text { (1997), } \mathrm{n}=71\end{array}$ & $\begin{array}{l}\text { CsA + MMF }(n=36) \\
\text { versus Tac + MMF } \\
(n=35)(\text { randomized }) \\
\text { historical control: } \\
\text { CsA-P }(n=100)\end{array}$ & $>2$ weeks & $\begin{array}{l}\text { 15/32 (46\%) for CsA and } 11 / 26 \\
\text { (42\%) for Tac; } 1 / 3 \text { of rejection } \\
\text { episodes occurred while } \\
\text { patients were still on steroids }\end{array}$ & $58 / 71(82 \%)$ & $\begin{array}{l}\text { Early SW decreased post-transplant diabetes, } \\
\text { hypercholesterolemia and hypertension } \\
\text { compared with historical control }(\mathrm{Cs} A+\mathrm{P})\end{array}$ \\
\hline $\begin{array}{c}\text { Trotter et al (82) } \\
\text { (2001), n=39 }\end{array}$ & $\begin{array}{r}\text { Tac }+\operatorname{Sir}(n=17) \text { or } \\
\text { CsA + Sir }(n=22)\end{array}$ & 3 days & $10 / 33(30 \%)$ & $26 / 33(79 \%)$ & $\begin{array}{l}\text { Compared with historical control: identical } \\
\text { patient and graft survival rates, } \\
\text { less rejection, less need for OKT3 }\end{array}$ \\
\hline
\end{tabular}

*Percentage of patients ultimately withdrawn from steroids. CsA Cyclosporine; MMF Mycophenolate mofetil; P Prednisone; Sir Sirolimus; Tac Tacrolimus

Steroid avoidance - too much of a good thing?

There are several advantages to the complete avoidance of corticosteroids after liver transplantation. Especially important are the prevention of increased viral replication early after transplantation and the prevention of side effects, such as osteoporosis and atherosclerosis, that last long beyond withdrawal. The rejection rate appears to be low with appropriate use of newer immunosuppressive agents, and these agents can reverse acute rejection episodes. These theoretical advantages have to be carefully balanced against the potential risks of increasing nonsteroidal immunosuppression, such as greater nephrotoxicity associated with CNIs (76), a higher incidence of viral infections (eg, cytomegalovirus, Epstein-Barr virus, post-transplantation lymphoproliferative disorder and HCV) with MMF (77) and severe hepatitis $\mathrm{C}$ with the use of anti-IL-2receptor antibodies (78).

Early studies of complete steroid avoidance in liver transplantation yielded various success rates; a significant number of patients subsequently required steroid treatment for rejection $(58,79)$. The first trials in liver transplantation using steroid-free immunosuppressive protocols are summarized in Table 3.

In an uncontrolled trial, Ringe et al (76) treated 30 patients with tacrolimus, MMF and intraoperative steroids, but no steroids after transplantation. The incidence of acute rejection in this trial was $26 \%$, and all episodes were reversed with shortterm steroid administration (17 patients received steroids temporarily or permanently). Only 13 of 30 patients $(43 \%)$ in their series never received steroids after liver transplantation. Nevertheless, $73 \%$ were ultimately maintained on steroid-free immunosuppression at two years. Ten patients presented within the first two months after transplantation with renal impairment requiring hemofiltration. In seven patients, renal failure was associated with high tacrolimus levels $(20 \mu \mathrm{g} / \mathrm{L}$ or greater $)$.

Of particular interest is the randomized, controlled study of 71 patients by Eason et al (80). Rabbit antithymocyte globulin, without steroids, was compared with the combination of steroids, tacrolimus and MMF. Seven of the 36 patients randomized to receive antithymocyte globulin experienced rejection, which resolved in all cases after the dosage of tacrolimus 
TABLE 3

Prospective studies on steroid avoidance in liver transplantation

\begin{tabular}{|c|c|c|c|c|}
\hline Reference (year), $n$ & Immunosuppression & $\begin{array}{c}\text { Rate of rejection } \\
\text { with steroid treatment }\end{array}$ & $\begin{array}{l}\text { Rate of long-term } \\
\text { steroid treatment }\end{array}$ & Remarks \\
\hline $\begin{array}{l}\text { Tisone et al (58) } \\
\text { (1999), } \mathrm{n}=45\end{array}$ & $\begin{array}{l}C s A+A Z A+P(n=22) \\
\text { versus } C s A+A Z A(n=23) \\
\quad(\text { randomized })\end{array}$ & $\begin{array}{l}10 \%(2 / 19) \text { in each group } \\
(3 \text { and } 4 \text { early deaths in the } \\
\text { steroid and control group } \\
\text { unrelated to rejection }\end{array}$ & $\begin{array}{l}0 \% \text { in both groups beyond } \\
\text { three months after } \\
\text { transplantation }\end{array}$ & $\begin{array}{l}\text { Patients in the steroid avoidance group } \\
\text { showed lower levels of alkaline } \\
\text { phosphatase and gamma-GT early } \\
\text { post-transplant, lower lipid levels, } \\
\text { and less diabetes }\end{array}$ \\
\hline $\begin{array}{l}\text { Rolles et al (79) } \\
\qquad(1999), n=64\end{array}$ & $\begin{array}{c}\text { CsA }(n=34) \text { versus Tac }(n=30) \\
\text { monotherapy (randomized) }\end{array}$ & $\begin{array}{l}\text { 14/34 (42\%) (CsA group) } \\
\text { 18/30 (60\%) (Tac group) }\end{array}$ & $\begin{array}{l}36 \% \text { (CsA group); } 13 \% \text { (Tac } \\
\text { group) after median follow-up } \\
\text { of } 26 \text { (range } 19 \text { to } 33 \text { ) months }\end{array}$ & $\begin{array}{l}\text { Only eight patients in each group did not } \\
\text { receive any steroids }\end{array}$ \\
\hline $\begin{array}{l}\text { Watson et al (81) } \\
\text { (1999), } \mathrm{n}=15\end{array}$ & $\begin{array}{l}\text { Sir }+\operatorname{Cs} A+P(n=4) \text { versus } \\
\text { Sir }+\operatorname{CsA}(n=7) \text { versus } \\
\quad \operatorname{Sir}(n=4)\end{array}$ & $\begin{array}{l}\text { 3/4 (Sir group); } \\
2 / 7 \text { (Sir + CsA group) }\end{array}$ & $\begin{array}{l}0 \% \text { beyond } 3 \text { months after } \\
\text { transplantation }\end{array}$ & $\begin{array}{l}\text { High mortality in this pilot study (five of } \\
15 \text { patients died) }\end{array}$ \\
\hline $\begin{array}{l}\text { Ringe et al (76) } \\
(2001), n=30\end{array}$ & Tac + MMF pilot study & $8 / 30(26 \%)$ & $\begin{array}{l}8 / 30(27 \%) \text { after mean follow-up } \\
\text { of } 597 \text { (range } 44 \text { to } 1224 \text { ) days }\end{array}$ & $\begin{array}{l}\text { Renal impairment in } 30 \% \text { of patients } \\
\text { consequent to higher Tac levels }\end{array}$ \\
\hline $\begin{array}{l}\text { Eason et al (80) } \\
\qquad(2001), n=71\end{array}$ & $\begin{array}{c}\text { RATG + Tac + MMF }(n=36) \\
\text { versus Tac }+ \text { MMF + P } \\
(n=35)(\text { randomized })\end{array}$ & $\begin{array}{l}\text { 0\% (RATG group); } \\
\quad 7 / 36(20 \%) \text { (steroid group) }\end{array}$ & $\begin{array}{l}0 \% \text { at any time point in the } \\
\text { steroid-free group }\end{array}$ & $\begin{array}{l}\text { In the steroid-free group, the study showed } \\
\text { a trend toward a lower rejection rate, } \\
\text { decreased incidence of postorthotopic } \\
\text { liver transplantation diabetes, less } \\
\text { recurrent hepatitis C and decreased } \\
\text { CMV infection }\end{array}$ \\
\hline
\end{tabular}

AZA Azathioprine; CMV Cytomegalovirus; CsA Cyclosporine; GT Glutamyltransferase; MMF Mycophenolate mofetil; P Prednisone; RATG Rabbit antithymocyte globulin; Sir Sirolimus; Tac Tacrolimus

was increased. None of these patients required steroids. The longterm prevalence of renal dysfunction and post-transplantation lymphoproliferative disorder are not yet reported in this patient group.

Three preliminary studies of sirolimus have been conducted (81-83). In a pilot study (81) of 15 patients, acute rejection occurred in two of seven patients (29\%) receiving CsA and sirolimus but no steroids; in none of four patients treated with CsA, sirolimus and steroids (for 42 to 84 days); and in three of four patients on steroid-free sirolimus monotherapy. Two of the patients in the last group had steroid-resistant rejection. Four patients required dialysis in the early postoperative period. In a pilot study of early steroid withdrawal, 39 patients were randomized to sirolimus and either CsA or tacrolimus, and all patients received a tapering schedule of methylprednisolone for three days (82). Rejection was experienced by 10 of 33 patients (30\%), and comparison with a historical control showed similar results for patient and graft survival. A third study was a nonconsecutive series of 56 patients treated with tacrolimus, sirolimus and steroids (83). Steroids were discontinued between three and 12 months after surgery in $91 \%$ of patients, and were restarted for immune suppression in one patient and for colitis exacerbation in another. The incidence of acute rejection was $14 \%$. Sirolimus dosage reduction was required in 22 patients, primarily for hematological abnormalities, and there was one episode of hepatic artery thrombosis. This combination allowed a reduction of the tacrolimus dosage, which resulted in improved renal function compared with conventional tacrolimus or CsA use in this population.

\section{CONCLUSIONS}

Corticosteroids have historically been part of immunosuppression regimens in liver transplant recipients. There are ample accumulated data to document the adverse effects of steroids in important patient groups. Steroids have been reported to adversely affect HBV, HCV and hepatocellular carcinoma, and to promote the development of PTDM and metabolic bone disease. Nevertheless, well-structured prospective trials documenting the benefits of steroid avoidance or early withdrawal are lacking.

More recent studies with CNIs and more potent adjuvant agents, such as MMF and sirolimus, with or without induction therapy, suggest that complete steroid avoidance is achievable, with acceptable rates of rejection. These studies suggest that steroid avoidance may be at least as easily achievable as steroid weaning. New immunosuppressive agents will need to be equally easy to handle and monitor, and be comparable with steroids in cost. Prospective randomized trials are needed to determine the role of steroids and how to balance efficacy in preventing rejection, the risk of disease recurrence and safety.

\section{REFERENCES}

1. Stegall MD, Everson G, Schroter G, Bilir B, Karrer F, Kam I. Metabolic complications after liver transplantation. Diabetes, hypercholesterolemia, hypertension, and obesity. Transplantation 1995;60:1057-60.

2. Citterio F. Steroid side effects and their impact on transplantation outcome. Transplantation 2001;72(Suppl 12):S75-80.

3. Migita K, Eguchi K, Kawabe Y, et al. Apoptosis induction in human peripheral blood $\mathrm{T}$ lymphocytes by high-dose steroid therapy. Transplantation 1997;63:583-7.

4. Scheinman RI, Cogswell PC, Lofquist AK, Baldwin AS Jr. Role of transcriptional activation of I kappa B alpha in mediation of immunosuppression by glucocorticoids. Science 1995;270:283-6

5. Auphan N, DiDonato JA, Rosette C, Helmberg A, Karin M. Immunosuppression by glucocorticoids: Inhibition of NF-kappa B activity through induction of I kappa B synthesis. Science 1995;270:286-90.

6. Karin M. New twists in gene regulation by glucocorticoid receptor: Is DNA binding dispensable? Cell 1998;93:487-90. 
7. Bianchi M, Meng C, Ivashkiv LB. Inhibition of IL-2-induced JakSTAT signaling by glucocorticoids. Proc Natl Acad Sci U S A 2000;97:9573-8

8. Wang JH, Devalia JL, Sapsford RJ, Davies RJ. Effect of corticosteroids on release of RANTES and sICAM-1 from cultured human bronchial epithelial cells, induced by TNF-alpha. Eur Respir J 1997;10:834-40.

9. Jobling AI, Augusteyn RC. What causes steroid cataracts? A review of steroid-induced posterior subcapsular cataracts. Clin Exp Optom 2002;85:61-75.

10. van Staa TP, Leufkens HG, Cooper C. The epidemiology of corticosteroid-induced osteoporosis: A meta-analysis. Osteoporos Int 2002;13:777-87.

11. Clowes JA, Peel N, Eastell R. Glucocorticoid-induced osteoporosis. Curr Opin Rheumatol 2001;13:326-32.

12. Fine RN. Growth following solid-organ transplantation. Pediatr Transplant 2002;6:47-52.

13. Sarna S, Sipila I, Vihervuori E, Koistinen R, Holmberg C. Growth delay after liver transplantation in childhood: Studies of underlying mechanisms. Pediatr Res 1995;38:366-72.

14. Margarit $C$, Martinez Ibanez V, Tormo R, Infante D, Iglesias $H$. Maintenance immunosuppression without steroids in pediatric liver transplantation. Transplant Proc 1989;21:2230-1.

15. Dunn SP, Falkenstein K, Lawrence JP, et al. Monotherapy with cyclosporine for chronic immunosuppression in pediatric liver transplant recipients. Transplantation 1994;57:544-7.

16. McKee M, Mattei P, Schwarz K, Wise B, Colombani P. Steroid withdrawal in tacrolimus (FK506)-treated pediatric liver transplant recipients. J Pediatr Surg 1997;32:973-5.

17. Asonuma K, Inomata Y, Uemoto S, et al. Growth and quality of life after living-related liver transplantation in children. Pediatr Transplant 1998;2:64-9.

18. Superina RA, Zangari A, Acal L, DeLuca E, Zaki A, Kimmel S. Growth in children following liver transplantation. Pediatr Transplant 1998;2:70-5.

19. Gambertoglio JG, Vincenti F, Feduska NJ, Birnbaum J, Salvatierra O Jr, Amend WJ Jr. Prednisolone disposition in cushingoid and noncushingoid kidney transplant patients. J Clin Endocrinol Metab 1980;51:561-5.

20. Bergrem H, Jervell J, Flatmark A. Prednisolone pharmacokinetics in cushingoid and non-cushingoid kidney transplant patients. Kidney Int 1985;27:459-64.

21. Jindal RM, Sidner RA, Milgrom ML. Post-transplant diabetes mellitus. The role of immunosuppression. Drug Saf 1997;16:242-57.

22. Steinmuller TH, Stockmann M, Bechstein WO, Settmacher U, Jonas S, Neuhaus P. Liver transplantation and diabetes mellitus. Exp Clin Endocrinol Diabetes 2000;108:401-5.

23. Markell MS, Armenti V, Danovitch G, Sumrani N. Hyperlipidemia and glucose intolerance in the post-renal transplant patient. J Am Soc Nephrol 1994;4(Suppl 8):S37-47.

24. Mason AL, Lau JY, Hoang N, et al. Association of diabetes mellitus and chronic hepatitis C virus infection. Hepatology 1999;29:328-33.

25. The US Multicenter FK506 Liver Study Group. A comparison of tacrolimus (FK 506) and cyclosporine for immunosuppression in liver transplantation. The US Multicenter FK506 Liver Study Group. N Engl J Med 1994;331:1110-5.

26. Baid S, Cosimi AB, Farrell ML, et al. Posttransplant diabetes mellitus in liver transplant recipients: Risk factors, temporal relationship with hepatitis $\mathrm{C}$ virus allograft hepatitis, and impact on mortality. Transplantation 2001;72:1066-72.

27. Padbury RT, Gunson BK, Dousset B, et al. Steroid withdrawal from long-term immunosuppression in liver allograft recipients. Transplantation 1993;55:789-94.

28. Stegall MD, Everson GT, Schroter G, et al. Prednisone withdrawal late after adult liver transplantation reduces diabetes, hypertension, and hypercholesterolemia without causing graft loss. Hepatology 1997;25:173-7.

29. Gomez R, Moreno E, Colina F, et al. Steroid withdrawal is safe and beneficial in stable cyclosporine-treated liver transplant patients. J Hepatol 1998;28:150-6.

30. Shapiro AM, Geng Hao E, Lakey JR, Finegood DT, Rajotte RV, Kneteman NM. Defining optimal immunosuppression for islet transplantation based on reduced diabetogenicity in canine islet autografts. Transplantation 2002;74:1522-8.

31. Weir MR, Fink JC. Risk for posttransplant diabetes mellitus with current immunosuppressive medications. Am J Kidney Dis $1999 ; 34: 1-13$
32. Lau JY, Bain VG, Smith HM, Alexander GJ, Williams R. Modulation of hepatitis B viral antigen expression by immunosuppressive drugs in primary hepatocyte culture. Transplantation 1992;53:894-8.

33. Wong PY, Marinos G, Peakman M, et al. FK506 in liver transplantation for chronic hepatitis B: In vitro studies on lymphocyte activation and virus replication. Liver Transpl Surg 1995;1:362-70.

34. Petersen J, Dandri M, Gupta S, Rogler CE. Liver repopulation with xenogenic hepatocytes in B and T cell-deficient mice leads to chronic hepadnavirus infection and clonal growth of hepatocellular carcinoma. Proc Natl Acad Sci U S A 1998;95:310-5.

35. Greenberg HB, Robinson WS, Knauer CM, Gregory PB. Hepatitis B viral markers in severe viral hepatitis: Influence of steroid therapy. Hepatology 1981;1:54-7.

36. Scullard GH, Smith CI, Merigan TC, Robinson WS, Gregory PB. Effects of immunosuppressive therapy on viral markers in chronic active hepatitis B. Gastroenterology 1981;81:987-91.

37. Ras E, Michaeli J, Rosenmann E, Popovtzer MM, Polliack A, Shouval D. Excessive hepatitis-B surface antigen production after corticosteroids and the development of immunoblastic lymphoma. Leuk Lymphoma 1993;10:241-4.

38. Ohtsu T, Sai T, Oka M, Sugai Y, Tobinai K. Activation of hepatitis $B$ virus infection by chemotherapy containing glucocorticoid in hepatitis B virus carriers with hematologic malignancies. Jpn J Clin Oncol 1991;21:360-5.

39. Samuel D, Muller R, Alexander G, et al. Liver transplantation in European patients with the hepatitis B surface antigen. N Engl J Med 1993;329:1842-7.

40. Bain VG, Kneteman NM, Ma MM, et al. Efficacy of lamivudine in chronic hepatitis B patients with active viral replication and decompensated cirrhosis undergoing liver transplantation. Transplantation 1996;62:1456-62.

41. Grellier L, Mutimer D, Ahmed M, et al. Lamivudine prophylaxis against reinfection in liver transplantation for hepatitis B cirrhosis. Lancet 1996;348:1212-5.

42. Markowitz JS, Martin P, Conrad AJ, et al. Prophylaxis against hepatitis B recurrence following liver transplantation using combination lamivudine and hepatitis B immune globulin. Hepatology 1998;28:585-9.

43. Steinmuller T, Seehofer D, Rayes N, et al. Increasing applicability of liver transplantation for patients with hepatitis B-related liver disease. Hepatology 2002;35:1528-35.

44. Sanchez-Fueyo A, Restrepo JC, Quinto L, et al. Impact of the recurrence of hepatitis $\mathrm{C}$ virus infection after liver transplantation on the long-term viability of the graft. Transplantation 2002;73:56-63.

45. Feray C, Caccamo L, Alexander GJ, et al. European collaborative study on factors influencing outcome after liver transplantation for hepatitis C. European Concerted Action on Viral Hepatitis (EUROHEP) Group. Gastroenterology 1999;117:619-25.

46. Berenguer M, Prieto M, San Juan F, et al. Contribution of donor age to the recent decrease in patient survival among HCV-infected liver transplant recipients. Hepatology 2002;36:202-10.

47. Berenguer M. Natural history of recurrent hepatitis C. Liver Transpl 2002;8(Suppl 1):S14-8.

48. Ghobrial RM, Farmer DG, Baquerizo A, et al. Orthotopic liver transplantation for hepatitis C: Outcome, effect of immunosuppression, and causes of retransplantation during an 8-year single-center experience. Ann Surg 1999;229:824-31.

49. Ghobrial RM, Steadman R, Gornbein J, et al. A 10-year experience of liver transplantation for hepatitis C: Analysis of factors determining outcome in over 500 patients. Ann Surg 2001:234:384-93.

50. Di Martino V, Brenot C, Samuel D, et al. Influence of liver hepatitis $\mathrm{C}$ virus RNA and hepatitis $\mathrm{C}$ virus genotype on FASmediated apoptosis after liver transplantation for hepatitis C. Transplantation 2000;70:1390-6.

51. Di Martino V, Saurini F, Samuel D, et al. Long-term longitudinal study of intrahepatic hepatitis $\mathrm{C}$ virus replication after liver transplantation. Hepatology 1997;26:1343-50.

52. Pelletier SJ, Raymond DP, Crabtree TD, et al. Hepatitis C-induced hepatic allograft injury is associated with a pretransplantation elevated viral replication rate. Hepatology 2000;32:418-26.

53. Rosen HR, Shackleton CR, Higa L, et al. Use of OKT3 is associated with early and severe recurrence of hepatitis $\mathrm{C}$ after liver transplantation. Am J Gastroenterol 1997;92:1453-7. 
54. Berenguer M, Prieto M, Cordoba J, et al. Early development of chronic active hepatitis in recurrent hepatitis $\mathrm{C}$ virus infection after liver transplantation: Association with treatment of rejection. J Hepatol 1998;28:756-63.

55. Brillanti S, Vivarelli M, De Ruvo N, et al. Slowly tapering off steroids protects the graft against hepatitis $\mathrm{C}$ recurrence after liver transplantation. Liver Transpl 2002;8:884-8.

56. Gane EJ, Naoumov NV, Qian KP, et al. A longitudinal analysis of hepatitis $\mathrm{C}$ virus replication following liver transplantation. Gastroenterology 1996;110:167-77.

57. Magy N, Cribier B, Schmitt C, et al. Effects of corticosteroids on HCV infection. Int J Immunopharmacol 1999;21:253-61.

58. Tisone G, Angelico M, Palmieri G, et al. A pilot study on the safety and effectiveness of immunosuppression without prednisone after liver transplantation. Transplantation 1999;67:1308-13.

59. Garcia-Retortillo M, Forns X, Feliu A, et al. Hepatitis C virus kinetics during and immediately after liver transplantation. Hepatology 2002;35:680-7.

60. Langrehr JM, Neumann UP, Lang M, et al. First results from a prospective randomized trial comparing steroid-free induction therapy with tacrolimus and MMF versus tacrolimus and steroids in patients after liver transplantation for HCV. Transplant Proc 2002;34:1565-6

61. Filipponi F, Salizzoni M, Grazi G, Pisati R, Ferrara R. Study of simulect-based, steroid-free immunosuppressive regimen in $\mathrm{HCV}+\mathrm{de}$ novo liver transplant patients: Preliminary results. Transplant Proc 2001;33:3211-2.

62. Mazzaferro V, Regalia E, Doci R, et al. Liver transplantation for the treatment of small hepatocellular carcinomas in patients with cirrhosis. N Engl J Med 1996;334:693-9.

63. Bismuth H, Majno PE, Adam R. Liver transplantation for hepatocellular carcinoma. Semin Liver Dis 1999;19:311-22.

64. Vivarelli M, Bellusci R, Cucchetti A, et al. Low recurrence rate of hepatocellular carcinoma after liver transplantation: Better patient selection or lower immunosuppression? Transplantation 2002;74:1746-51.

65. Yokoyama I, Carr B, Saitsu H, Iwatsuki S, Starzl TE. Accelerated growth rates of recurrent hepatocellular carcinoma after liver transplantation. Cancer 1991;68:2095-100.

66. Freise CE, Ferrell L, Liu T, Ascher NL, Roberts JP. Effect of systemic cyclosporine on tumor recurrence after liver transplantation in a model of hepatocellular carcinoma. Transplantation 1999;67:510-3.

67. Mazzaferro V, Rondinara GF, Rossi G, et al. Milan multicenter experience in liver transplantation for hepatocellular carcinoma. Transplant Proc 1994;26:3557-60.

68. Majewski M, Korecka M, Kossev P, et al. The immunosuppressive macrolide RAD inhibits growth of human Epstein- Barr virustransformed B lymphocytes in vitro and in vivo: A potential approach to prevention and treatment of posttransplant lymphoproliferative disorders. Proc Natl Acad Sci USA 2000;97:4285-90.
69. Hidalgo M, Rowinsky EK. The rapamycin-sensitive signal transduction pathway as a target for cancer therapy. Oncogene 2000;19:6680-6.

70. Jain A, Kashyap R, Marsh W, Rohal S, Khanna A, Fung JJ. Reasons for long-term use of steroid in primary adult liver transplantation under tacrolimus. Transplantation 2001;71:1102-6.

71. McDiarmid SV, Farmer DA, Goldstein LI, et al. A randomized prospective trial of steroid withdrawal after liver transplantation. Transplantation 1995;60:1443-50.

72. Everson GT, Trouillot T, Wachs M, et al. Early steroid withdrawal in liver transplantation is safe and beneficial. Liver Transpl Surg 1999;5(Suppl 1):S48-57.

73. Trouillot TE, Shrestha R, Kam I, Wachs M, Everson GT. Successful withdrawal of prednisone after adult liver transplantation for autoimmune hepatitis. Liver Transpl Surg 1999;5:375-80.

74. Belli LS, de Carlis L, Rondinara G, et al. Early cyclosporine monotherapy in liver transplantation: A 5-year follow-up of a prospective, randomized trial. Hepatology 1998;27:1524-9.

75. Washburn K, Speeg KV, Esterl R, et al. Steroid elimination 24 hours after liver transplantation using daclizumab, tacrolimus, and mycophenolate mofetil. Transplantation 2001;72:1675-9.

76. Ringe B, Braun F, Schutz E, et al. A novel management strategy of steroid-free immunosuppression after liver transplantation: Efficacy and safety of tacrolimus and mycophenolate mofetil. Transplantation 2001;71:508-15.

77. Mathew TH. A blinded, long-term, randomized multicenter study of mycophenolate mofetil in cadaveric renal transplantation: Results at three years. Tricontinental Mycophenolate Mofetil Renal Transplantation Study Group. Transplantation 1998;65:1450-4.

78. Nelson DR, Soldevila-Pico C, Reed A, et al. Anti-interleukin-2 receptor therapy in combination with mycophenolate mofetil is associated with more severe hepatitis $\mathrm{C}$ recurrence after liver transplantation. Liver Transpl 2001;7:1064-70.

79. Rolles K, Davidson BR, Burroughs AK. A pilot study of immunosuppressive monotherapy in liver transplantation: Tacrolimus versus microemulsified cyclosporin. Transplantation 1999;68:1195-8.

80. Eason JD, Loss GE, Blazek J, Nair S, Mason AL. Steroid-free liver transplantation using rabbit antithymocyte globulin induction: Results of a prospective randomized trial. Liver Transpl 2001;7:693-7.

81. Watson CJ, Friend PJ, Jamieson NV, et al. Sirolimus: A potent new immunosuppressant for liver transplantation. Transplantation $1999 ; 67: 505-9$

82. Trotter JF, Wachs M, Bak T, et al. Liver transplantation using sirolimus and minimal corticosteroids (3-day taper). Liver Transpl 2001;7:343-51

83. McAlister VC, Peltekian KM, Malatjalian DA, et al. Orthotopic liver transplantation using low-dose tacrolimus and sirolimus. Liver Transpl 2001;7:701-8.

84. Stegall MD, Wachs ME, Everson G, et al. Prednisone withdrawal 14 days after liver transplantation with mycophenolate: A prospective trial of cyclosporine and tacrolimus. Transplantation 1997;64:1755-60. 


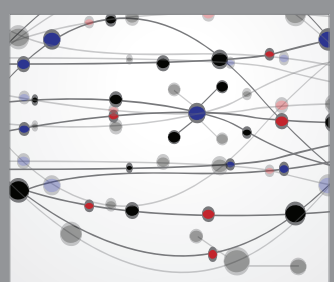

The Scientific World Journal
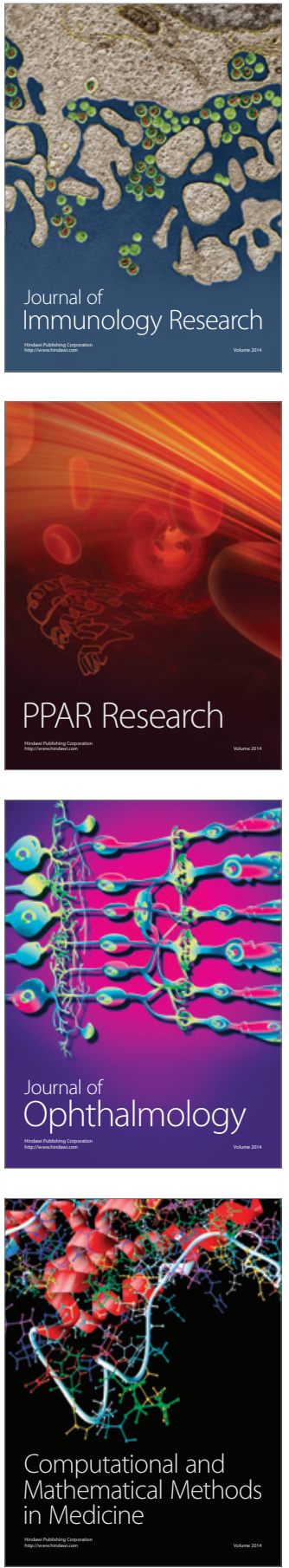

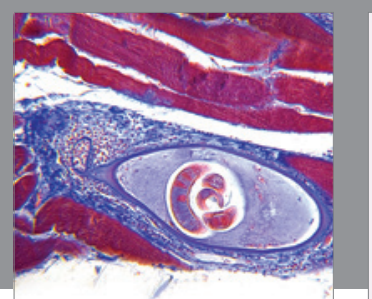

Gastroenterology Research and Practice

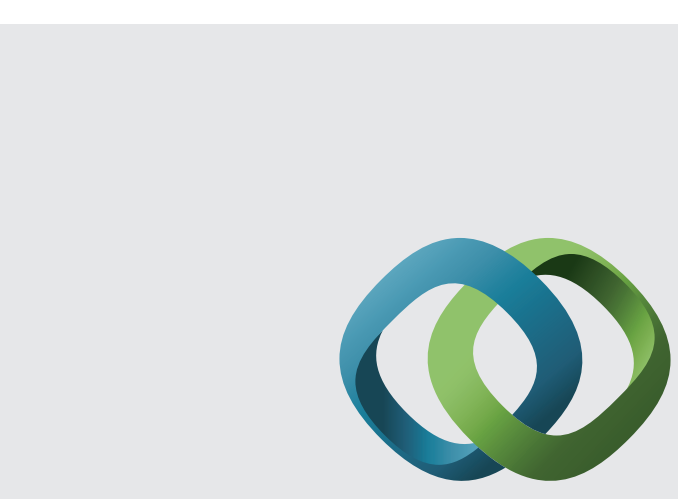

\section{Hindawi}

Submit your manuscripts at

http://www.hindawi.com
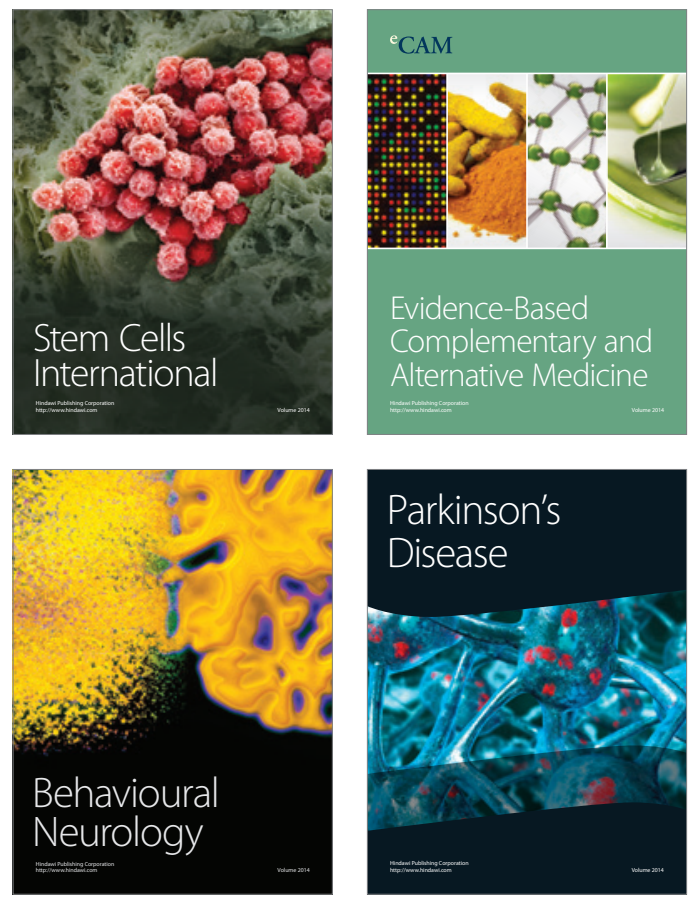
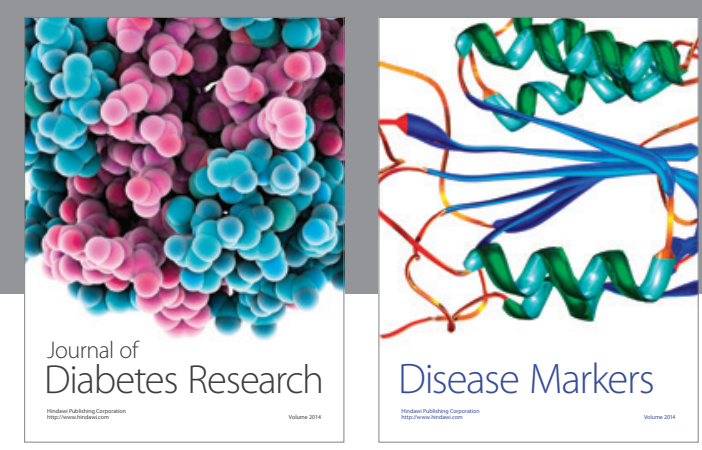

Disease Markers
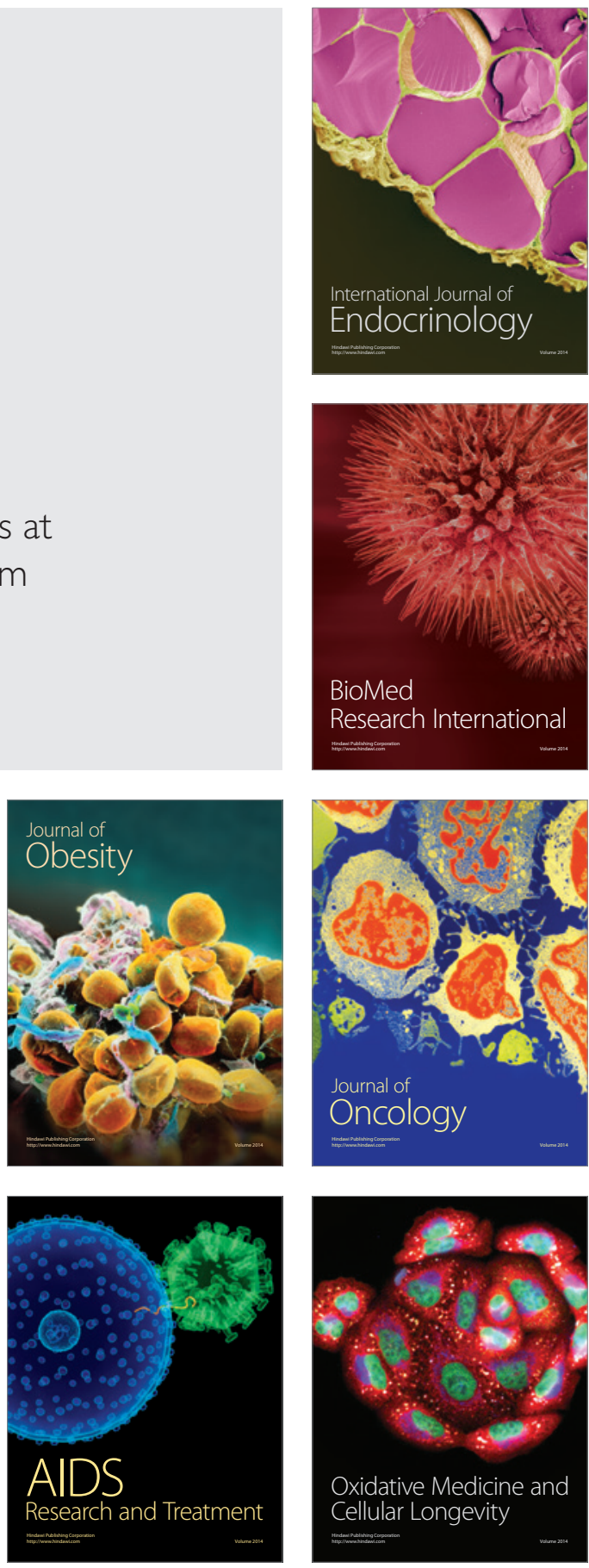